\title{
6 Archipelagos of Designing Through Ko-Ontological Encounters
}

\author{
Yoko Akama
}

\section{Acknowledging Our Bodies in Place}

There is a deep warmth that hums inside me when I see the majestic gum trees waving and listen to the Lorikeets gossip over breakfast. I am grateful for the peach-grey skies above the urban rooftops that herald another day.

I was born in Japan, but I have been living and working in Melbourne, on east Kulin lands, since 2002. I acknowledge the unceded sovereignty of the Traditional Custodians, the Woi Wurrung and Boon Wurrung mobs of the Kulin Nation, and pay my respect to their elders, past, current and emerging. My respect also extends to all Aboriginal and Torres Strait Islander peoples of Australia.

I also pay my respect to all Traditional Custodians of the lands, waters, animals, forests and skies where this text might be read. I extend my respect to all Indigenous and First Nations ancestors and elders, and I am grateful for their cultural wisdoms that may teach us how to re-entangle with many sentients of our worlds.

I open with a public 'Acknowledgement of Country', which is offered at most formal and public gatherings in Australia. When I do this Acknowledgement, I ground my presence to country. I call upon the rituals deep inside me when respecting elders, ancestors and the sentience of more-than-humans. Such rituals of respect have been habituated since my birth, such as visiting our local shrine or offering gratitude at our Buddhist altar at home in Japan. My utterance is imbued with spirit-kotodama (spirituality of words). As an uninvited Japanese visitor to Aboriginal lands, the ritual of Acknowledgement allows me to be present and supplicate with kokoro (heart-bodyspirit) to honour the Traditional Custodians. I will be returning to the significance of rituals later.

The formal 'Welcome to Country', offered by Traditional Custodians, is generous and powerful. Womienjeka in the Woi Wurrung language is commonly interpreted as 'hello', but I have also learned from N'arweet Carolyn Briggs (Boon Wurrung Elder) that it is a request to state one's purpose: Why are you here? What is your purpose? (RMIT, 2020). The Welcome by a Traditional Custodian comes with obligations. As an intruder on these lands, I take seriously the commitment to obey the laws of Bundjil, Kulin's creator deity, to not harm the land (biik biik), waterways (wurneet) and children (bubups) of Bundjil while I dwell in their country. From friend and colleague, Peter West (2020), I have also learned that Acknowledgement is a reply and acceptance of the terms and laws to engage with Indigenous sovereignty.

www.ulapland.fi/ArtsBasedMethodsForDecolonisingParticipatoryResearch/Chapter6

DOI: $10.4324 / 9781003053408-6$ 
Stating one's purpose, to me, is an obligation to bring your whole self to a sovereign encounter, to have a respectful sovereign relationship with Aboriginal people. I was taught the importance of this from Wiradjuri and settler friends (Tye et al., 2020; West, 2020). To me, bringing your whole self calls upon one's entire relationality-ancestry, family, place where you are from-to an encounter. I am not an individual, disconnected from these things. Acknowledging our lineage also obliges us to attend to the scars in our family histories and to learn from the wise and painful experiences of our elders. Such obligations participate in a wider movement of ethical practice of locating oneself that has relevance beyond settler-migrants on colonised lands (see for example Agid \& Chin, 2019; Linström \& Ståhl, 2020; Rizvi, 2018) and also to remind us of our pre-existing relationalities. The past for many of us is very much alive.

Three pairs of chopsticks.

The long black one is Dad's.

Mum has a lacquered pair in indigo.

The red one, chipped in many places, is mine. I've had it since I was a teenager.

It's always been the three. These are set on the table at every breakfast.

A bit of a cliché I know, but it is the most important meal of the day.

A time we're together as a family.

I am the only daughter of Chiaki and Kinue. Chiaki, my dad, grew up on a farm in rural Hokkaido (north island of Japan). He is the youngest son of 13 children of a migrant railway worker. Dad was born just when the Pacific War started and he was the only one who went to university in Tokyo, far from his birthplace, carrying with him hopes of his entire family to take them out of poverty. He studied economics, taught himself English and was employed by a multinational trading company at a time when Japan was entering its period of high economic growth. Our nuclear family migrated with him to different cities around the world. He ensured our financial security and never once hesitated to support the tutoring that I needed to keep up with my Japanese and local education. He was a typical 'salary man'-one of an army of workers who shouldered the burden of rebuilding post-war Japan through a lifetime of dedication to their companies. Demands from work meant we saw very little of him. When his colleagues were dying from karoshi (work-related exhaustion) (Kanai, 2009), I grew up thinking his absence at home was normal. Japanese innovation and technology are generally celebrated without acknowledging the harsh and private sacrifices by workers and their families. The times I affectionally remember are his delight in helping me with my schoolwork, and how I was his clever little daughter who learned to speak perfect English. He would have been a brilliant maths teacher, if he had that choice. I am so grateful to him for teaching me about loyalty, resilience, discipline and the value of education.

Kinue, my Mum, was born in northeast China, then Manchuria, occupied by the Japanese army when my teenage grandfather was stationed there. Boys like him were sent to the front line by sacrificing their lives to the Emperor, who was believed by most people in Japan to be a deity until Japan lost the Pacific War. Every August, when Japan marks its end, my mum weeps with shame and compassion. The atrocities by the imperial forces in the Asia-Pacific will never to be forgotten. I, too, will carry 
that sorrow, shame and compassion for what history has implicated us in. Like most women at the time, my mum was not permitted to go to university, despite her intelligence, proactiveness and charisma. She went to finishing school in Japan to learn domestic science, then married to serve her husband and the family. She is a proud housekeeper, the most amazing cook, incredibly thrifty, sociable and creative. I have her hands and nimble fingers, and she has taught me to be a maker. Her hands are my grandmother's hands that stitched kimono for the three daughters. I continue to be inspired by what I see as 'social innovation' projects she is involved with in our local community. She takes me to the rice paddies to find pesticide-free water snails to feed the fireflies she breeds that have gone extinct from our local river. I am awed by the care she shows for the seemingly ignoble larvae that spends most of its life in mud. Every summer, when they are released along stretches of the river cleaned by the community, locals of all ages gather to share joy in their fleeting beauty and their return.

Because of my family circumstances, I grew up in various countries and gained heightened sensitivity to plurality, and this has led me to acknowledge my responsibility for being entangled in the violence of colonial structures. Global forces, political power and world histories have shaped our family, just as it has yours.

\section{You and I are a product of this worlds' continual becoming. ${ }^{1}$}

\section{Holding and Carrying}

I opened with an 'Acknowledgement of Country' as a way of being embodied on sovereign lands to state where I am. Acknowledging in this way challenges prevailing anthropocentricity because place is already plural. Beyond common ways place is defined for its significance by humans, places are also sentient (Inoue et al., 2003; Moran et al., 2018). The land where our ancestors are from, and the various places where we were taken or choose to dwell, also shape who we are and become.

I introduced my family, ancestry and the conditions that have shaped who I am becoming. In so doing, I am avoiding co-option by the hegemony of whiteness. Rarely shared are descriptions of the researchers' (or practitioners') backgrounds, sociocultural context, values, philosophies and where/how their world views are shaped. Critical social psychology scholars Adams and Salter (2019, p. 273) evoke a powerful metaphor of a white lab coat that researchers wear in exchange of their identities, to 'promote a sense of abstraction from social, historical, and material contexts' of a privileged position. Their argument is compelling because the lab coat is a metaphor for whiteness associated with 'epistemic perspectives of racial power', going beyond being culturally neutral or the absence of colour, towards a 'thinly disguised directive for assimilation to a particular racial position' (p. 273). In other words, designers and researchers that choose, by default, to be nowhere and nobody are at risk of being concealed by whiteness. For many Black, Indigenous and people of colour, this is not a choice; rather, whiteness is a violent structure that can render them as invisible nowhere and nobody (Fanon, 1994).

Neutrality and placeless-ness are conflated with impartiality, rendering invisible the importance of race, gender, class and such experiences to matter by their disavowal. The common parlance for knowledge sharing is also bound by the unfortunate structures of standard English 'preoccupied with abstraction or with nothing/nobody evidently alive' (Jordan, 1985, p. 130). These symptoms of whiteness are evident in Dominant 
Design and Research, fortifying a cycle of nowhere and nobody (Suchman, 2002). I will be using the uppercase ' $D$ ' to refer to professional norms and ossified understandings as 'Dominant Design' (or just Design) in an attempt to distinguish this from ethical, situated and ontological notions of designing (in lower case) throughout this chapter.

Whiteness is a continuing legacy of colonialism, Indigenous dispossession, slavery, segregation and immigrant exclusion where we are all living within structures and conditions of racial hierarchy (Crenshaw, 2019). The omnipotence of whiteness makes it the 'unmarked norm against which difference is measured' (Gerding, 2019, p. 24). This is the world we have inherited and these histories surface on our bodies (Ahmed, 2011). Dominant Design is complicit in designing worlds of whiteness and future of others, because designing is shaped by ontologies, and also shapes ontologies: 'We design our world, while our world acts back on us and designs us' (Willis, 2006, p. 80). This means Design is never innocent of the way it structures and hardbakes whiteness as the standard bearer. In designing bodies, behaviours, imaginations and futures, Design is also ontological in its whiteness and in its affect. These range from literal and visible ways in which 'White Standards' promote cosmetic products to affirm paler skins as notions of 'beauty' (Kabai as cited in Onafuwa, 2018), Design technologies that do not recognise darker skin tones (Ogbonnaya-Ogburu et al., 2020), elevation of the creativity of designers in Silicon Valley to cast 'Asians as mathematical, unaesthetic, rule-oriented' pool for outsourcing labour (Irani, 2018, p. 11) and the representation of Africans as impoverished and/or illiterate users in HCI [Human Computer Interaction]' (Bidwell, 2016, p. 24). The examples go on, and they are everywhere. The attention I give here is because of Dominant Design's invasiveness: 'Our ontological stances about what the world is, what we are, and how we come to know the world define our being, our doing, and our knowing-our historicity' (Escobar, 2018, p. 92).

The approach I have taken in this chapter reveals layers of entanglements that I am already participating in, in different ways. Recognising our entanglements obliges us to be more sensitive to how we participate in existing structures, dynamics and rhythms in collaborative designing and research. I welcome others to 'hold and carry' these approaches with them to disrupt the legacies and desires of neutrality, objectivity and placeless-ness in Dominant Design. It is a way that complicates simplifications of race, class, gender, age, ethnicity, religion, sexual orientation and other systems of economic, political and ideological conditions of binary oppressions. This relationality is an intersectional matrix that asserts varying levels of disadvantages and privileges (Collins, 1990), in relation to when, where, and who I am with. This also signals a way to accommodate the hermeneutic way this text might be read by you, dear reader, and such reading also changes our positionalities in dynamic ways. You and your ancestries may be from lands invaded by Japanese forces, including the Indigenous islands of Ryukyu (Okinawa) and Ezo (Hokkaido). You might be reading this in North America or Australia, where legacies of prejudice linger from the time when citizens of Asian descent were labelled 'enemy aliens' and interned in camps. You may be a person fascinated with cultural exports from Japan and the variety of terms taken and applied in Euro-American contexts. In other words, my lineage and being a Japanese woman already entangles me in all of these histories, perceptions and more. This means my positionality is always in-between $(M a)$, dynamically moving in relation to yours (in the Sea of $M a$-more on this later), even though this writing will remain fixed in time. Such shifts also include flaws and immaturity in my emerging 
consciousness about how I should be in Design Research. Its predominant whiteness means my Japanese body and being will always be challenged. Nothing is permanent, or at least, from my world view, and I would like to see how we can keep that notion alive during our encounters here.

\section{$\mathrm{Ko}$-Ontologies of Inter-Becoming}

In starting from body and place as ontologies of locating, I also add kokoro as another significant ontology-a resonant quality of being and becoming-with. Dominant Design's modern roots has meant that spirituality has been accorded little importance, eroded through religious, political and social reform in the pursuit of progress and technological advancements in northern Europe (Walker, 2013). Resisting the disparagement of spirituality is another act of decolonising. For me, 'Acknowledging Country' is kokoro-a resonant responsiveness with place uttered through the spirituality of words (kotodama). Respecting Bundjil and ancestors is through kokoro-a resonant responsiveness with sentiency of more-than-humans. I aim to design and research with kokoro. In fact, my being and becoming-with-many is all kokoro. Kokoro is often poorly translated as 'heart and mind', reflecting the Cartesian detachment in 'Standard English' (Jordan, 1985), when in fact, kokoro is a quality that arises in interrelatedness of mind-heart-body-soul-spirit that are already and always inseparable. This is why I appreciate the way Kasulis (2002, p. 25), a notable Asian philosopher, describes kokoro as 'a resonant responsiveness'. I dedicate a large portion of this chapter to the significance of kokoro and designing as one example from the archipelago of Japan.

Kokoro collapses mind-constructed categories and locates resonance in the inbetweens of plurality. Like the letters 'co' added to recognise the plurality of human and more-than-human actors that participate as co-designing or co-ontology, my meaning of 'co' is in fact closer to the 'ko' of kokoro. In other words, replacing the 'co' with ' $k o$ ' in designing and ontology enables me to include the inter-becoming of body-spirit-place that is often omitted in Design. While it might appear like a trite re-labelling, I am trying to take advantage of affordances when writing Japanese Roman English as kokoro (『心』or『こころ』in Japanese), because of our Englishwriting-reading encounters. This enables me to discuss ko-designing and ko-ontology as an expanded resonant responsiveness and relational in-between later on. Continuing this strategy of ruffling conventional writing-reading, I have woven fragments in italics to invite a ko-ontological, expansive encounters for resonant responsiveness that lies beyond rational argumentation. Altogether, another offer I make to holding and carrying is to experience $k o$-ontological ways we are inter-thinking, inter-acting, inter-being and inter-becoming-with-many in plural worlds. I encounter you and worlds through-with-as kokoro.

However, we must be vigilant in appropriating concepts and ontologies for the service of human-centred politics, which makes me reluctant to 'use' the notion of spiritual and plural ontologies of kokoro for decolonising. Like Professor Sheehan, who looks up at night to 'see knowledge reflected in the Country of the universe' (Moran et al., 2018, p. 75), certain kinds of consciousness and ontologies are beyond the realms of human minds and histories. As we shall see, the references to rituals and practices I speak of are sacred. I will also address the importance to respect knowledge and ontologies without needing to know fully. 


\section{Yoko Akama}

This will likely disappoint readers looking for customary footholds for replicable and generalisable methods for decolonising Design. This is not a 'how to' collaborate with Indigenous people (for guidance, please see the International Indigenous Design Charter), though some of what I address might be relevant. Here, we must pause to query why and where expectations for transferability comes from that assume methods and knowledge can be untethered from the sites of their relational embodiment and moved elsewhere like a package (Akama et al., 2019). Instead, I offer other forms of learning that I hope are significant: the effort of unlearning and unsettling, being prompted to reflect and question, and entangling one's own experiences and understanding. Most importantly, I foreground ontology for methods and methodology to enact as decolonising. This means I premise inter-becoming ( $k o$-ontologies) by acknowledging the whole self of being embodied on sovereign lands and recognising one's entire relationality to resist whiteness that renders one as nowhere and nobody. I aim for our ko-ontological encounters by being expansive with structures of language and writing, and using metaphors and poetry to invoke alternative imaginaries, resonating with the artist, writer and colleague Paul Carter (2019), who has inscribed metaphorical literacy to think figuratively in decolonising discourses.

\section{Archipelagos: Sea of Islands}

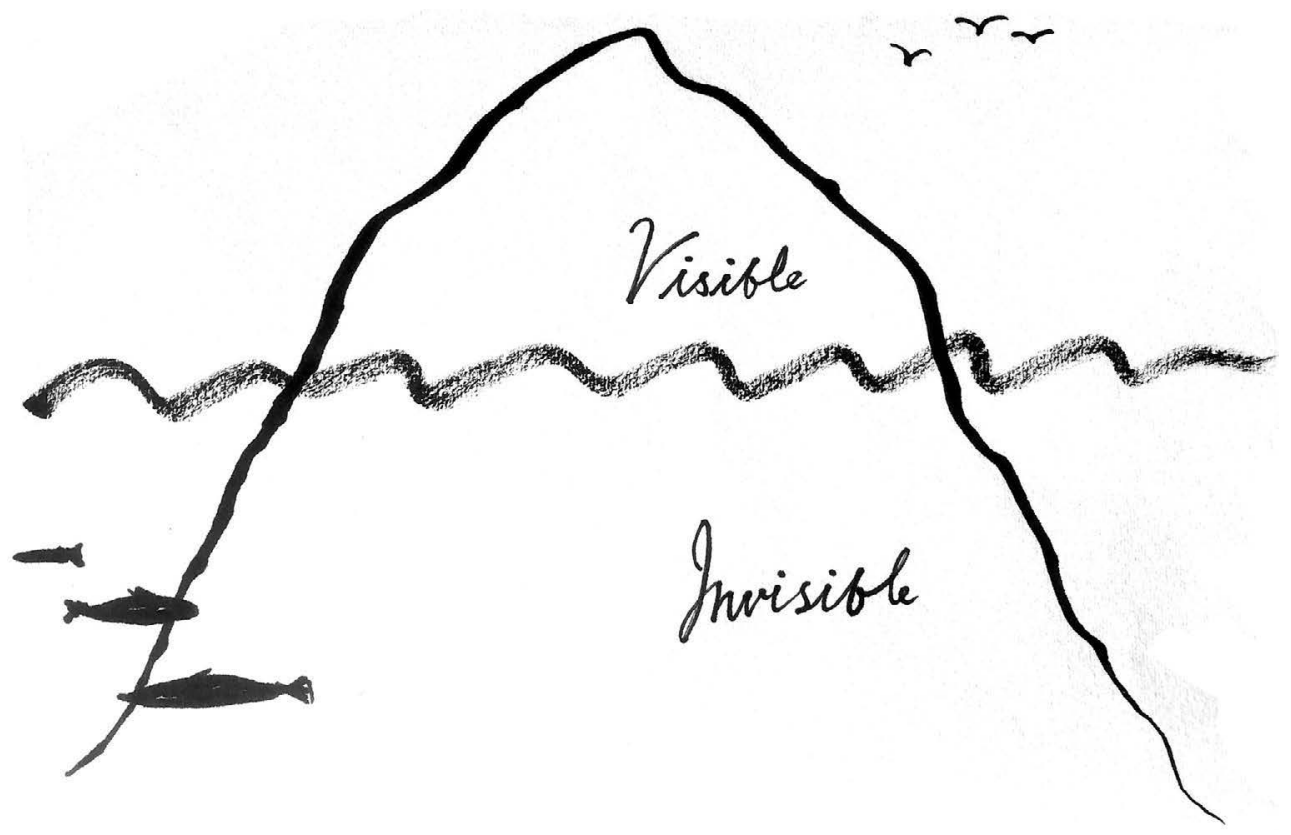

Figure 6.1 Island of visibility and invisibility.

I have been using islands as a metaphor (Figure 6.1) to teach introductory constructs to those learning more about design. Cultural theory and anthropology scholars have offered a model whereby cultures can be likened to an iceberg, composed of layers that can be easily observed in the upper levels and those that are less visible below the surface (Giddens, 1984; Hofstede, 1994). While the unitary and generalisable model of an iceberg is problematic (more on this later), nonetheless, the image 
helps to convey the visibility of products, tools, methods, behaviours and touchpoints that are supported by the underlying layers of values, mindsets and world views, which are harder to see. For example, the replicable Double Diamond model, visible and used commonly in Design, manifest and amplify the values that lie beneath the surface, such as problem-solving, simplicity, efficiency and linear progress (Akama et al., 2019). The island metaphor invites learners of Design to embark on decolonising by understanding and respecting various values and world views under the water line, to avoid assuming what is visible on the surface as styles, techniques and knowledges that can be transferred and replicated. The International Indigenous Design Charter (n.d.) has been created because Design has followed, and continues to follow, colonial acts of acquisition, so we must remain vigilant.

Design has accompanied modern world-making practices to be useful, effective, functional, durable, seductive, convenient, original and innovative, and has been used to solve problems for others, grow market share and increase customer satisfaction. We can see this most clearly in Service Design, where operations management and systems thinking influences have further elevated the belief that complete understanding of systems and their parts is possible (Agid \& Akama, 2018). Our paper also noted that methods, such as Customer Journey Maps and Blueprints, have become mainstream proxies for 'real-world' models to universalise individual experiences by stripping away cultural, social, geographical and political dimensions. Service Design, like its parent Design, has become a powerful agent in advancing ideologies of growth, control, competition, productivity and neoliberal capitalism. It is a concern shared by Escobar (2018), who has talked about the paradox of fixing modern problems with

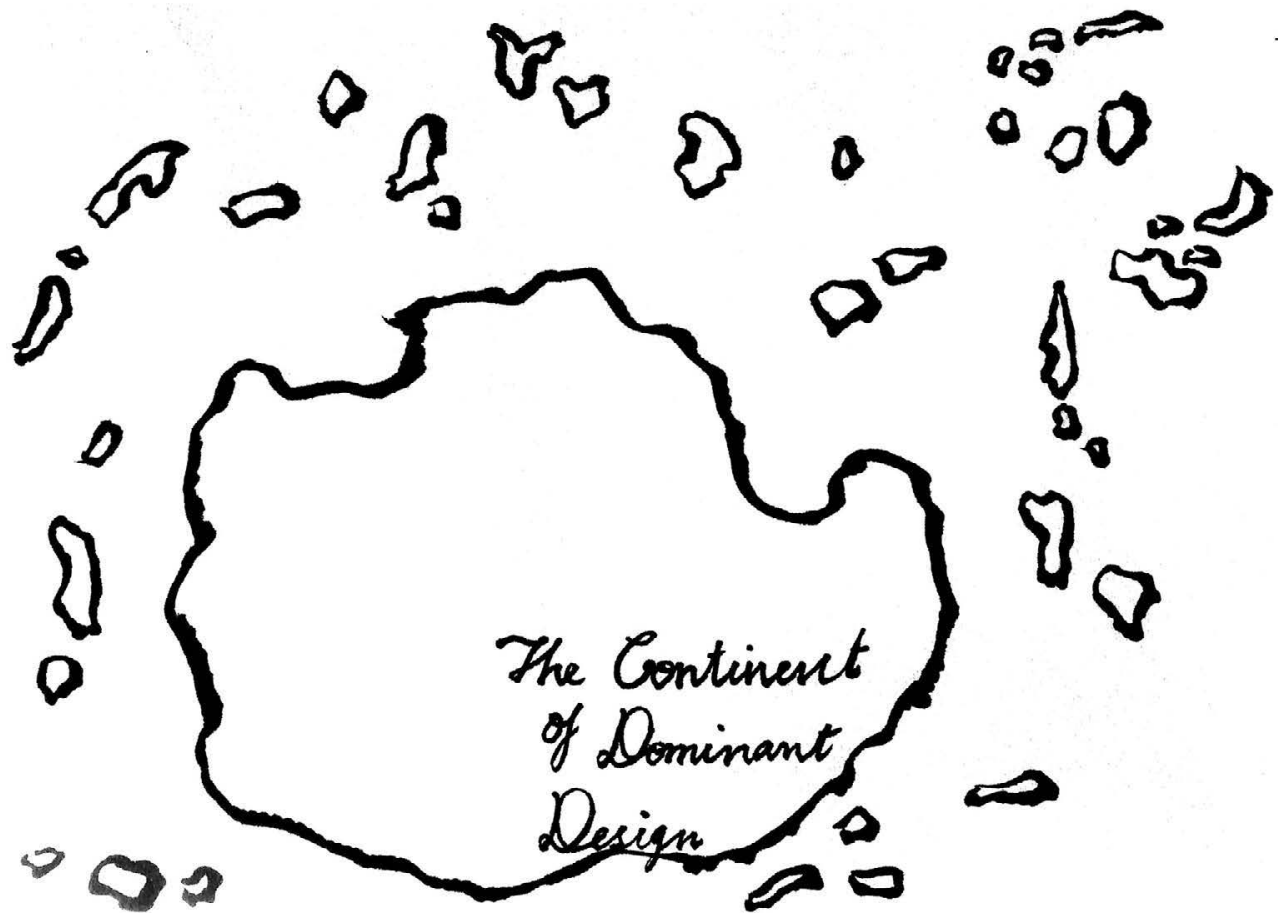

Figure 6.2 The Continent of Dominant Design. 
modern solutions, especially if these problems stem from modern world-making practices that have erased and subjugated divergent onto-epistemologies and world views.

To show how Dominant Design has become the central frame of reference for this discipline, I draw 'The Continent of Dominant Design' (Figure 6.2) as a massive island in the middle, just as cartographers of the past have visualised, magnified and centralised their particular nations on their own map to demarcate power and territories. Dominant Design is similarly positioned in status. The scale, centrality and universality are metaphors of 'One-World' hegemony (Escobar, 2018; Law, 2011) imbued with modern colonial values and world views that lie under the water's surface.

However, I also draw 'The Continent of Dominant Design' as nested within archipelagos. Archipelagos unsettle iceberg models that suggests universality, detachment and containment, and also troubles island tropes that connote singularity, isolation, insularity and periphery. Archipelagos have enabled relational and non-binary ways to think and be with in the broader humanities to premise reciprocal connectivity (Hau'ofa, 1994), as an ontology of mobilities and multiplicities (Stratford et al., 2011), creatively imagine possibilities (McEntee et al., 2016), prefigure transfiguration and metamorphosis (Pugh, 2013), and 'islandness' as a relationality of emplacement (Oliver, forthcoming). Decolonising is not treated here as a metaphor (Tuck \& Yang, 2012), rather, metaphors can activate expansive dialogue in decolonising (Carter, 2019). I surround the Continent with a sea of islands to indicate that there are various forms of designing that express and cyclically shape many kinds of values and world views.

The metaphor of archipelagos refers to significant constellations of designing that are ignored, exoticised, universalised or often appropriated by 'The Continent of Dominant Design'. The archipelagos act as an invitation for all to identify designing that has been ongoing under other names as both specialised and everyday practices. Design researcher Gutiérrez Borrero have called these practices diseños con otros nombres: 'designs with other names' (Calderón Salazar \& Guitérrez Borrero, 2017). These reminders compel us to take responsibility to relate to other names, forms, articulations and practices of designing by paying closer attention to what is below the water line that matters to groups of people. As a design student trained by Dominant Design in the UK and Australia, and later, as a maturing practitioner and design researcher, I know how powerful the desire is to be legitimised (see Akama et al., 2019). This meant that I, too, in the past, felt the need to define and only account essential characteristics of designing by using Simon's $(1968$, p. 55) popular approach to 'devise courses of action aimed at changing existing situations into preferred ones' and to determine how things ought to be. I had to unlearn these deeply entrenched scripts as a mindful way of unlearning (see Akama, 2018).

For the remainder of this chapter, I will introduce a notion of designing that has been practised in Japan, an archipelago made up of more than 6,000 islands, which has been buffeted by various ideas, thoughts and world views carried along currents of trade, religion, conflict, migration and globalisation. It is important to state also that while I identify as a Japanese woman, I ask not to essentialise what I describe as inherently Japanese or lump it as 'Japanese Design'. Like an archipelago, there are numerous forms and expressions of designing in Japan. ${ }^{2}$ The particular rituals, poems, teachings, philosophies and quotidian practices I call attention to have been important to me in recognising a way designing can be understood. These are not theories with a capital T, or philosophies with a capital P, but they are intimately woven into the social fabric, having endured through centuries to shape how people inhabit and always-become-with-many worlds. This means I have used my own writing from 
other places because some of these weighty ideas have been developed elsewhere, and often in collaboration.

\section{Kokoro of Designing}

Kokoro is a commonly used term in Japanese that has expansive and holistic meanings. Kokoro is not an organ, or just a mindset or a feeling, but denotes qualities of interrelating. Thus, its use encompasses mind, heart, body, soul, spirit and emotions that are all involved in interrelating that enable kokoro to also mean empathy, essence, truth, virtue, naturalness, awakening and more. Owing to the influences in Taoism, Shinto and Zen Buddhism in Japan, kokoro is a reflection of embracing the sentiency of everything, so humans are not at the apex, and 'living beings' does not mean just those with cell division. This means kokoro is a quality of interrelating between and beyond humans and can be attributed to animals, plants, mountains, materials and objects, and also speeches, writings, drawings, music, weathers, waters and heavens. Kokoro infuses being and worlds as interrelatedness, entanglement and 'resonant responsiveness within the overlap between the world and the person' (Kasulis, 2002, p. 25).

The Japanese architect Isozaki (2011, p. 36) writes that 'erasing distance that separates subject and object-of becoming one with nature' is common across all creative fields in Japan, including design. He recalled a conversation with Isamu Noguchi who said, 'Facing a natural stone in silence, I begin to hear its voice. My work is just to follow the voice; my role is just to help it a little bit' (Noguchi as cited in Isozaki, 2011, p. 36). His statement has echoes of Sakuteiki, a guide for designing gardens, written in the twelfth century: 'The placement of the stone must follow the stone's request'. ${ }^{3}$ From this, we can learn that materials are not yielding themselves to service human needs or uses; rather, designing could be seen as a way for these materials and humans to engage through respecting their distinct materialness. The respect accorded to materials is celebrated as the aesthetics of naturalness and simplicity, but I worry how popular articulations of 'Japanese design' outside Japan is conflated with the modernist ethic of 'less is more' that strips away kokoro as a significant dimension, perhaps due to the impossibility of grasping its meaning in writing and in English. Like Noguchi, maybe we can move closer to kokoro through listening carefully to materials: 'The plain clay may speak for itself, but its voice is so soft that the potter of the mindful heart amplifies it so we can all hear it' (Kasulis, 2002, p. 44). We can sense in these accounts the intimacy of interrelatedness that does not separate self-other, human-nature or human-object. From this, we could say that the kokoro of designing aims to enhance the qualities of interrelatedness.

This world view of interrelatedness is founded on Shinto, the native spirituality of Japan, which anchors many traditions and current practices in domestic life. This spirituality is also referred to as Koshinto (ancient Shinto), because Shinto became a formalised religion when it was amalgamated with Buddhism in the early sixth century to unite and educate the nation (Gomi \& Toriumi, 2009). My engagement with Shinto is closer to Koshinto and not the religion that positioned the Emperor's divine supremacy to enforce imperial power, because I carry within me the horrors of my grandfather's wartime experiences, but also my spiritual being and relationship to Shinto has been densely woven by countless, everyday practices since my childhood.

Furutone river runs through my hometown, a few blocks behind our house. In the stillness that precedes the dawn, we quickly head to Mum's special spot along the river. Many of our neighbours are already there. 
We exchange muffled greetings-Akemashite omedetooo! Kotoshimo yoroshiku! - through our masks, scarves and foggy white puffs of a bone-chilling dawn.

We all wait in semi-darkness, gazing east.

The first ray of sun catches a whisker of cloud with a minted dazzle.

The New Year is here.

Everywhere, our hands are pressed together as we pray to the first sunrise.

Attending hatsubinode (New Year sunrise) is a ritual that many Japanese perform, stemming from an ancient practice of worshipping the sun. Some scholars have related Koshinto to animism, a view that the natural world is made of a community of spirits of which humans are just one part (Inoue et al., 2003). This spirituality has coexisted alongside successive Western influences from science, technology and industrialisation during the Meiji Restoration so that everyday items such as cooking pots, wooden clogs and paper lanterns (see Itaya [1860] on the Hyakki Yagyo scroll of a parade of supernatural creatures), as well as modern inventions like cars and robots (Geraci, 2006) are also imbued with kami - a term that loosely refers to gods, deities, souls and spirits. Its reference to any animate or inanimate being speaks to the diversity of kami (yaorozu no kami), which in turn, reflects the diversity of forms, rituals and encounters with kami across Japan.

Encountering kami has been likened to natural wonders such as seeing a spectacular sunrise (Kasulis, 2002). Awe is an overwhelming and humbling experience, a merging of self and other, forging the 'relationship with a power or force, an element of life that it is not only greater than the self but is ontologically different' (Elfers \& Hlava, 2016, p. 124). In Shinto, anything associated with kami is marked with a torii (gate) or shimenawa (rope), so we see shimenawa encircling rocks, trees, entrances to caves, islands, mountains and shrines, or hung around altars in homes. Kasulis (2002) interprets the shimenawa to be an act that serves as a 'bookmark' to tether us, in our busy, modern lives, to our connection to awe, intimacy and belonging with the world.

Various historians believe that, in ancient times, shrines were not buildings; instead, a shimenawa was hung to demarcate himorogi (a space of sanctum), and kami were called and welcomed there (Inoue et al., 2003; Yamada, 1966). This ritual for invoking kami continues today. Upon approaching the yashiro (hut) of a shrine, visitors bow-bow-clap-clap-bow. The style of these rituals varies across the regions, but this invocation is customary. These rituals mark ways of crossing over thresholds to avoid entering the grounds in haste and mindlessness. Walking through the torii gate and listening to the footsteps on pebbles prepares for an encounter, for kokoro to be open and 'empty' to be enveloped by awe and wonder. Kami are thought to be numerous and everywhere-yaorozu no kami-so the clapping is a form of awakening or concentrating their attention. These rituals are the means to draw on the power of kami (Yamada, 1966).

Rituals of invocation also extend to speech. Motoori Norinaga (1730-1801) was a famous scholar of the most ancient Japanese text, Köjiki, and the native oral Yamato language before Chinese scripts were imported. His contribution was significant in articulating kotodama as the spirit and sacredness of words. For Norinaga, poetry was words with kokoro (koto no kokoro) and the 'moving power of things'-mono 
no aware (Marra, 2011, p. 384). Building on Norinaga's contribution, Kasulis (2002, p. 26) further explained kokoro as resonant responsiveness:

The poet's kokoro resonates with the kokoro of the actual mountain mist and the kokoro of the Japanese words. Through the interpenetration and common responsiveness of these kokoro, the poem is produced. From this perspective, the poet alone does not write a poem about the mountain mist. More precisely, the mountain mist, the Japanese words and the poet write the poem together.

Here, we can see the respect afforded to immaterial and material worlds that are participating in resonant responsiveness, in how Norinaga articulates this state. One could say that designing can involve the same responsiveness to enhance the qualities of interrelatedness.

For Norinaga, waka (Japanese poetry) embodied the 'moving power of things' (mono no aware) to be drawn into a field of resonance-kokoro. This waka was composed by a famous poet and monk, Saigyo (1118-1190):

nanigotono owashimasukawa shiranudomo I know not what lies within katajikenasani namida koboruru but I am moved to tears with gratitude

When Saigyo visited Ise Shrine during the twelfth century, a pilgrimage destination regarded as one of the most ancient and sacred shrines in Japan, he composed this famous waka. Isozaki (2011, p. 125) explained that this poem 'expresses an awe inspired by the sacredness of Ise. The waka formula requires no logical explanation; the simple statement enters the hearer's heart and reverberates there-it is sheer power of language'. Here we see Isozaki referring to kotodama-the spiritual, sacred, primordial power of words. The moving power of Saikyo's waka and the awe-inspiring power of Ise combine to create an intense field of resonance-this is a ko-ontological encounter.

Ise Shrine is a significant reference for architects and designers due to several distinct features. Its architecture is said to reflect Yayoi-era structures that were used to store rice more than 2,000 years ago, reflecting Japan's agricultural roots. The most unique feature of Ise, however, is the ritual of dismantling and rebuilding its entire structure on an adjacent site every 20 years. These include 65 built structures including the gates (torii) that demarcate the threshold to the shrines, many yashiro (huts) for kami, bridges and 1,567 ritual objects. This is a practice called shikinen-sengu. These are all rebuilt anew to enable maintenance, and the used timbers are passed on to repair other shrines around the country. The whole township and region take part in this process. The central shin-no-mihashira (heart pillar) is a timber, at least 300 years old, that has been felled from the sacred mountains. This means that our ancestors planted these trees for this very purpose, 300 years ago and much earlier, for this ritual to have continued more than 1,000 years. The timbers are carried down the rivers and streets through various townships. When the sacred pillar is raised, the master builder chants a prayer, invoking the moving power of kotodama. I see the deconstruction and reconstruction reflect Shinto beliefs to celebrate life born, decaying and then extinguished, marking these cycles to orient passage through life to teach and remind us that nothing is permanent.

The use of significant resources to dismantle a structure every 20 years, only for it to be rebuilt again, may seem bizarre-especially to those that adhere significance 


\section{Yoko Akama}

to preserving historical architecture, much like restoring the Acropolis. In fact, both European and Japanese architects have equated Ise and the Acropolis in beauty, function, religious prominence and cultural originality in the world of modern architecture. This comparison was famously made by Taut, a German architect, in the 1930s, who 'elevated' Ise in international architectural hierarchy (Reynolds, 2001). Isozaki (2011, p. 125), however, was critical of positioning Ise 'on a Western scale of value'. He argued the 'mindset haunting modernity and its conflation with genealogy' is because it requires a 'discovery of origin ... to perform an evaluation' (p. 130). In other words, time is linear in the mindset of modernity, so a singular point or origin has to be created or defined from which things can be explained and measured. Preserving the original is a way to measure and assure values such as authenticity, durability, consistency and progress. Design, with its modern lineage, also expresses these values.

Yet, there is no 'origin' as such of Ise. Being a culturally significant site noted in the earliest written records of Japan, Nibonshoki, its entanglements are both deep and broad. Scholars are unable to verify its inception, as this matter is not about this one shrine but also concerns the politicisation of Shinto, which is and has been, associated with a variety of kami, beliefs, myths, events, rituals, ideologies and rulers, as well as the politics of writing and interpreting premodern histories (Hayashi, 1997; Loo, 2010; Reynolds, 2001). In all, instead of seeking foundational truths, we could say all manners of deliberate concealment and reconstruction have been the constant practice associated with Ise (Rambelli, 2014). This paradox fascinates scholars and lay people to continue re-interpreting the significance of Ise to this day, including myself, because both experience and documentation are intentionally shrouded. Instructions for the re-build are not written or turned into blueprints. The entire shrine complex is surrounded by four layers of sacred hedges. The ritual of renewal takes place in predawn darkness and behind silk veils. Such secrecy may arouse suspicion for religion, tradition and myths in those who value logic, transparency and public verifiability (Kasulis, 2002). The same values underlie 'blind' peer-reviews in Design Research that determine what knowledge is deemed important to Design.

However, many forms of onto-epistemes are embodied in practices, and they are legitimate, available to those proximal with an affinity to such practices. This is true for Japanese philosophy (Kasulis, 2002) and in creative practice research (Barret \& Bolt, 2007). During Ise's reconstruction, countless adjustments have taken place through many hands, techniques and materials in response to varying climates and resource scarcity. Over the centuries, its style has also incorporated Buddhist influences from Korea and China, and the cycles were often disrupted due to war and natural disasters. From this, we can see a way of designing that differs from Design, which does not promote values of clarity, originality, durability, rationalism or linear advancement. Isozaki sagely cautioned us not to seek origins because it also 'causes us to lose the point, abandoning the real object' (2011, p. 125). What I learned from Ise's ritual is that one can respect and appreciate 'contradictory' truths and wisdom without fully seeing, owning or understanding. It also taught me about the sacredness of knowledge and being mindful when crossing over thresholds. I will elaborate more on this in the concluding remarks.

The importance of what we cannot see, own or understand speaks most powerfully to me when standing in front of the site where the old shrines once stood (Figure 6.3). This space is 'empty', marked by white stones and an 'empty' wooden yashiro. Cleared, 'empty' sites are characteristics of shrines as seen in himorogi (cleared spaces 


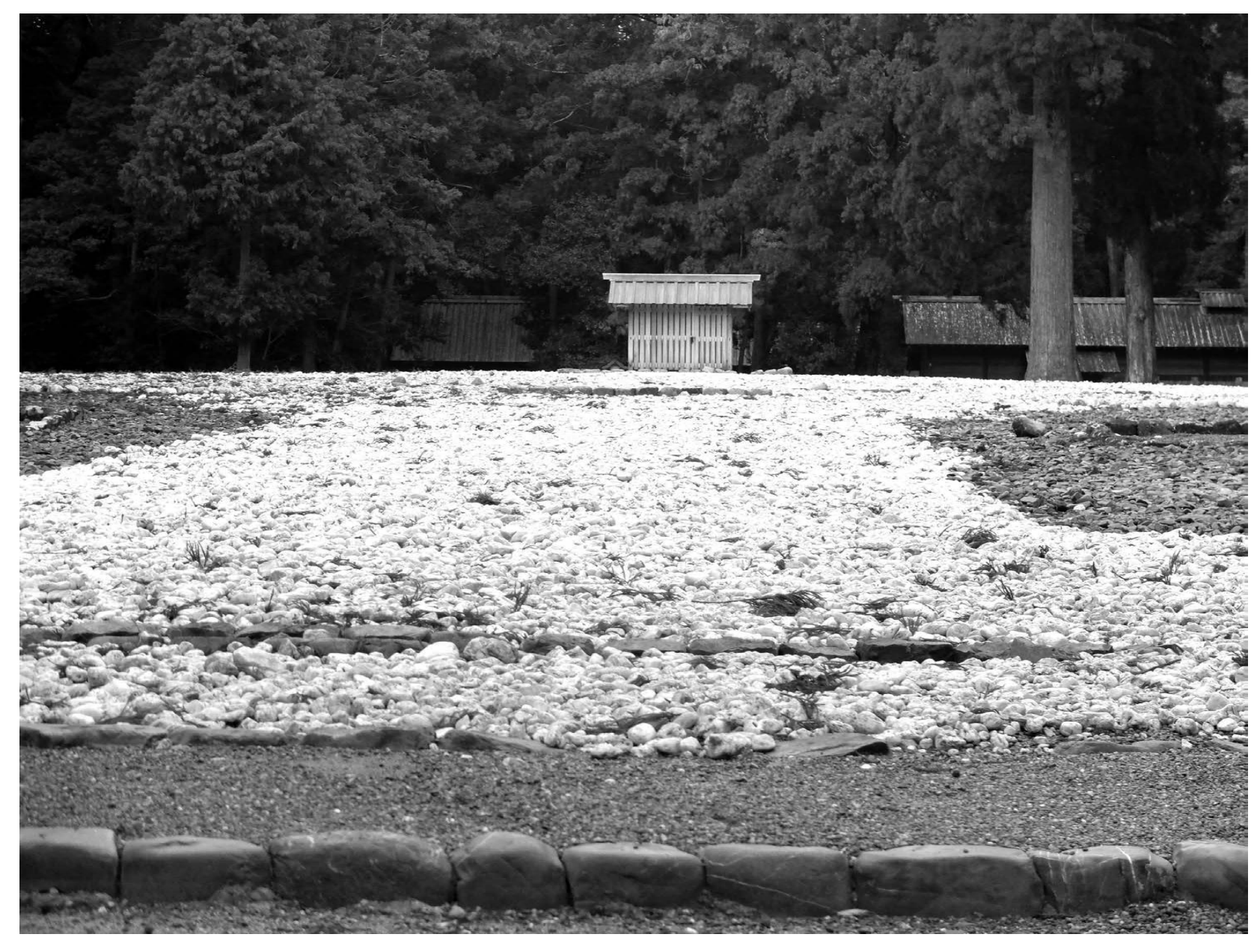

Figure 6.3 Geku Shrine, Ise. 


\section{Yoko Akama}

of sanctum) demarcated with shimenawa (rope). In other words, this 'emptiness' is the grounds for invoking kami. This 'empty' site is not disused or abandoned; rather, I see it as an ontological space that is anticipating and always-becoming-with. It reflects a world view shaped by philosophies of absence, where formlessness is the necessary grounds for being (Nishida as cited in Dilworth et al., 1998). It is this very emptiness that receives our presence and retains the 'possibility that something may enter it' because 'an empty state possesses a chance of becoming by virtue of its receptive nature' (Hara, 2011, p. 30). I come to Ise's teaching through this ontology of emptiness. This emptiness and cycles of dismantling and rebuilding are precisely what enables Ise Shrine to continue becoming-with.

Interrelatedness is seen in the 20-year cycles that maintain generational and community ties. Every material is handcrafted by a person as a sign of their respect and a gift to kami and community. Families bring their children to participate in Ise's various festivals as $u j i k o,{ }^{4}$ and these children, later when fully grown, continue to visit with their own families. A total of 230,000 people across Japan are selected via a ballot to participate in the stone-laying ritual (Teeuwen \& Breen, 2017). Each person offers one river-washed stone, wrapped in white cloth, to contribute to covering the whole ground to demarcate the sacred places that no one can enter. Apprentices commence their training to develop their craft over the decades to become masters who teach the next group of apprentices. While historical and contemporary patriarchy underpin gendered roles performed at shrines, the 20-year cycles maintain correspondence amongst a vast network of carpenters, artisans, construction workers, caretakers and communities to pass on knowledge, practices and stories. Generations have affectionately called the Shrine Oise-san ${ }^{5}$ and Ise Shrine continues to be a major a pilgrimage for the 14 million who visited during the last shikinen-sengu in 2013 and another 9.7 million during the 2020 New Year celebrations (Asahi Newspaper, 2020). The next shikinen-sengu will be in 2033.

In all, I provided one notion of designing that is relational to and with human, more-than-human and broader ecologies, imbued with ontologies, philosophies and spiritualities that have accompanied practices that continue today. Interrelating here is a way of being, learning and awakening a heightened awareness of relational sensitivity across plurality. This is what I see as kokoro of designing that seeks to enhance the qualities of interrelatedness. When such practices are collapsed under established canons of Co-design or Participatory Design, I hope you can see what politics are at play when this happens that omit a way of interrelating beyond materials, projects, infrastructures and human-centred timespans. To me, kokoro of designing resonates across a deeper, broader scale and plurality of 'participants'.

\section{Departing and Sailing}

Thinking with archipelagos is a reminder that islands are plural and have never been isolated (Hau'ofa, 1994). This means we can find alliances by forging ties and learning amongst one another, as well as find the courage, support and inspiration to depart from the shores of the Continent. However, just as the metaphor of the Continent references colonial cartography that created universal, technical and imperial epistemologies to demarcate worlds and territories (Schultz, 2018) for us here, it is a reminder to be vigilant about the violent acts of taking knowledge and resources from one part of the world to another, especially if we have already been conditioned with 
values that they should always be free, accessible and transportable. In other words, when we sail to other archipelagos of designing, it is important to understand that the act of departure and travel is an arduous effort.

The labour of unlearning entrenched conditioning, mindsets and habits can be challenging, as it often requires one to be open, uncertain and vulnerable (Rose, 2004). Alongside Shinto, I also continue to draw upon Zen teachings, such as it is not our preference that causes problems but our attachments to them, because of the emphasis they give to mushin (mindfulness) as a way of letting go (see Akama, 2018). The word mushin, often associated with 'mindfulness', is written by combining $m u$ (emptiness) and kokoro. Mushin is a lifelong practice of clearing away preconceptions, distractions, habits and reactions to being mindful of what I am holding and carrying into places, relationships and occasions. It is an act of composure and readiness (Akama \& Light, 2018) to take responsibility for how we are already entangled. The introductory section spoke to the structures of whiteness and the efforts I am making to avoid remaining as nowhere and nobody. I know how it feels to be 'othered', so my practice also includes avoiding 'othering' anyone, such as labelling 'white people' as default oppressors. The powerful poetry of Audrey Lorde (2018) has taught us that 'the master's tool will never dismantle the master's house'. Her work powerfully speaks here to mean 'othering' oppressors only leads to swapping rooms within the same house of dualism, discrimination and disempowerment.

As we depart from 'The Continent of Dominant Design', this also signals a movement away from dualism and disempowerment. I see decolonising as powerful forces like the tectonic plates that broke up the supercontinent, Gondwanaland. Allies in decolonising in this collection, and beyond those I have cited, are doing this challenging and necessary work to dismantle hegemony and provide alternatives to those already conditioned with the modern and colonial scripts of Design. If decolonising is the powerful courage needed to depart the shores of the Continent, the archipelagos is a metaphor for plurality of many minds, places, perspectives and relationalities, as well as the fluidity and partiality of our own viewpoints. This means that archipelagos are not literal locations, nations or cultures, but they are where these pluralities can be embodied in ourselves. This echoes the work of friend and colleague James Oliver (forthcoming), who explains 'islandness' as 'inhabited complex of multiplicity'.

There are so many archipelagos of designing that manifest many kinds of ontologies, philosophies and spiritualities that have continued within industrialised societies. Sadly, there is no room here to include more, so instead, I recommend learning how designing has always been participating in becoming-with-many from those who are generously inviting us to listen and engage. For example, I have learned a great deal from the wisdom offered by Uncle Moran, Uncle Harrington and Professor Sheehan (2018, p. 73) in Australia on Indigenous knowledge that considers design as 'a natural and naturalizing power', and it is 'how all living beings co-operate and co-create'. This designing for 'mutually enhancing sustainable economies and sociotechnical systems' informs how Tristan Schultz (2018, p. 85) spearheads Indigenous Design Futures. Many contemporary Indigenous designers in architecture, urban planning, product design, communication design, fashion and textiles are drawing upon this significant heritage and wisdom, adapting, blending, evolving the notion of designing in ways to continue contributing to their communities and broader ecologies (Browning et al., 2017). 


\section{Yoko Akama}

From another archipelago, I learned from designer/researcher Diana Albarrán González (2020) the wisdom of Mayan Tsotsil and Tseltal peoples, a compelling form of decolonising and artisanal designing through Buen Vivir (good living, collective wellbeing) and Lekil Kuxlejal (a fair and dignified life). From Desna WhaangaSchollum, a founding member and Chairperson of Ngā Aho, a network of Māori design professionals, I learned about Te Ao Māori (Māori worlds) and the philosophies, principles, protocols, values and world views practised as Kaupapa Māori (Akama et al., 2019). With friends and colleagues Joyce Yee, Khemmiga Teerapong and Viola Petrella, we have begun to understand the significant role played by Lanna temples in Chiang Mai, Thailand, in sustaining designing and social innovation (Yee et al., 2020).

Plural worlds are embodied in these practices, which I find so compelling. These 'island to island' relationships (Stratford et al., 2011) have become a significant constellation by which to orientate my approach to navigating the eddies and currents that powerfully influence the movements of my practice and becoming-with. These encounters, often through invitation, have required me to listen and follow, guided by the host, while releasing and surrendering what I am holding on to and carrying with me. Like the rituals at a shrine, I aim to be mindful when crossing over thresholds and be open to encounters by acknowledging the sacredness of knowledge, the spirituality of words, and the sentiency of place and more-than-human beings. I aim to respect teachings, truths and wisdom without needing to know fully.

As we sail to many archipelagos, we must also learn how to respectfully embrace other perspectives, knowledges, practices, experiences and world views and attempt to rediscover or reorientate relationships. I use the term reorientation, with regards to those who were conditioned through systems of separation, omission and acquisition, as a way to encourage alternative ways of relating, of being entangled and implicated with one another. This resonates with what Tlostanova $(2017$, p. 54) has argued as 'multiple optics and many-valued logic' that can lead to a more radical rethinking of Design.

By acknowledging our fluid positionalities of our own knowing, being and worlding, we can enable differences to be premised and embraced. Yet, the irony of the 'diversity' agenda means that many of us who are identified as 'non-white' women are brought into spaces of whiteness to 'educate' or 'diversify' established groupings or ways of thinking. This labour is wearisome, but I take up such spaces as my duty and privilege towards creating conditions for plurality to flourish. Institutions have a way of 'managing diversity' to contain conflict and to make visible literal differences. The abstracted individuality of liberalism still threatens to flatten diversity because, as Ahmed (2012) noted, diversity is tolerated as long as it does not disrupt established structures. This means diversity is contained within pre-existing categories, much like filling out the grid of a table. Adding more content does not disrupt the stability of the grid, but it can make it appear diverse and equal. Extending Ahmed's critique, when diversity is seen as a threat to institutions like the establishment of disciplines, this means that we, as educators and researchers, must be careful not to participate in closed circularity and authority of the status quo, so that our systems of qualification, validation of knowledge and structures of education is not ossifying Dominant Design. Rather, in premising diversity, we must constantly be questioning what is taught or omitted, what is considered knowledge or dismissed, what is visible and promoted, and what is invisible under water and kept unseen. 


\section{Archipelagos: Sea of $M a$ (In-Betweens)}

It is curious how rational logic rejects incongruence when contradictions are always co-present and interrelated. Plurality is to respect knowing, being and worlding that are different and always will be irreconcilable. Zen teaches us that the notion of opposites consists of dualisms constructed by the linear mind (Suzuki, 1969). What appears as opposite poles to the linear mind might just be partial views from various archipelagos.

\section{One Day During Lockdown ${ }^{6}$ \\ Knowing smiles from strangers- \\ for now we have something in common besides the weather. \\ Why does avocado and vegemite on toast taste so good? \\ Paralysed by fear of not being able to say goodbye to my mother in person. \\ Watching the clouds bump into the sky. \\ News report of an outraged woman who was refused entry to a store for not wearing a face mask. A corner of my soul is ashamed to admit that we might be totally missing the teachings from the more-than-human virus deity.}

The disruption and persisting challenges of the pandemic are acute reminders that our experiences defy easy comparison or can collapse under the weight of a universal ontological equivalence. Contrary to the utopian imaginary of an island paradise, archipelagos are multibeing assemblages of flotsam and jetsam, continually whirling and creating dynamic forms that also intensifies, multiplies and disrupts relations of land, water, island and continent so it remains no longer a 'composition of things that are believed to fit together' (Stratford et al., 2011, p. 122). Similarly, various forces are always at work that buffet our being and becoming. The examples shared from Japan are familiar to neighbouring lands because there are well-worn shipping channels and trade routes where ideas and practices have travelled in-between. We are already entangled in evolutionary, geologically and globalising ways. Building on what I have previously written about $M a$ as between-ness and in-between created by the pre-existence of both and many (Akama, 2015), the space in-between $(M a)$ the islands are just as important to the archipelagos. Philosophy and ontologies of $\mathrm{Ma}$ 'denies the position of a fixed subject' (Isozaki as cited in Davidson, 1991, p. 66). The currents and channels in-between are the Sea of $M a$ (Figure 6.4) that maintains a correspondence, co-emergence and sensitivity that is neither one nor another, to remain entangled in the flux and flow of changing and becoming-with-many. The Sea of $M a$ can be a metaphor for many things where supposedly 'incongruent', 'contradictory' or 'incommensurate' knowledges, experiences, ontologies and cosmologies as currents intermingle, and have always intermingled, to compose new things. In other words, rather than emphasising sameness or fearing divergence, connections and resonance can be found in difference when plurality is embraced in its own right (Carter, 2019). This reinforces that archipelagos are not literal locations, nations or cultures, but a metaphor for how these pluralities can be embodied in ourselves.

Being at sea is unsettling. These in-betweens can be a contested space of turbulence, tension and survival for those whose onto-epistemologies continue to be ignored and belittled (Nakata, 2007). It can create anxiety for those conditioned by the Continent who fear that their engagement might result in misappropriation and further 


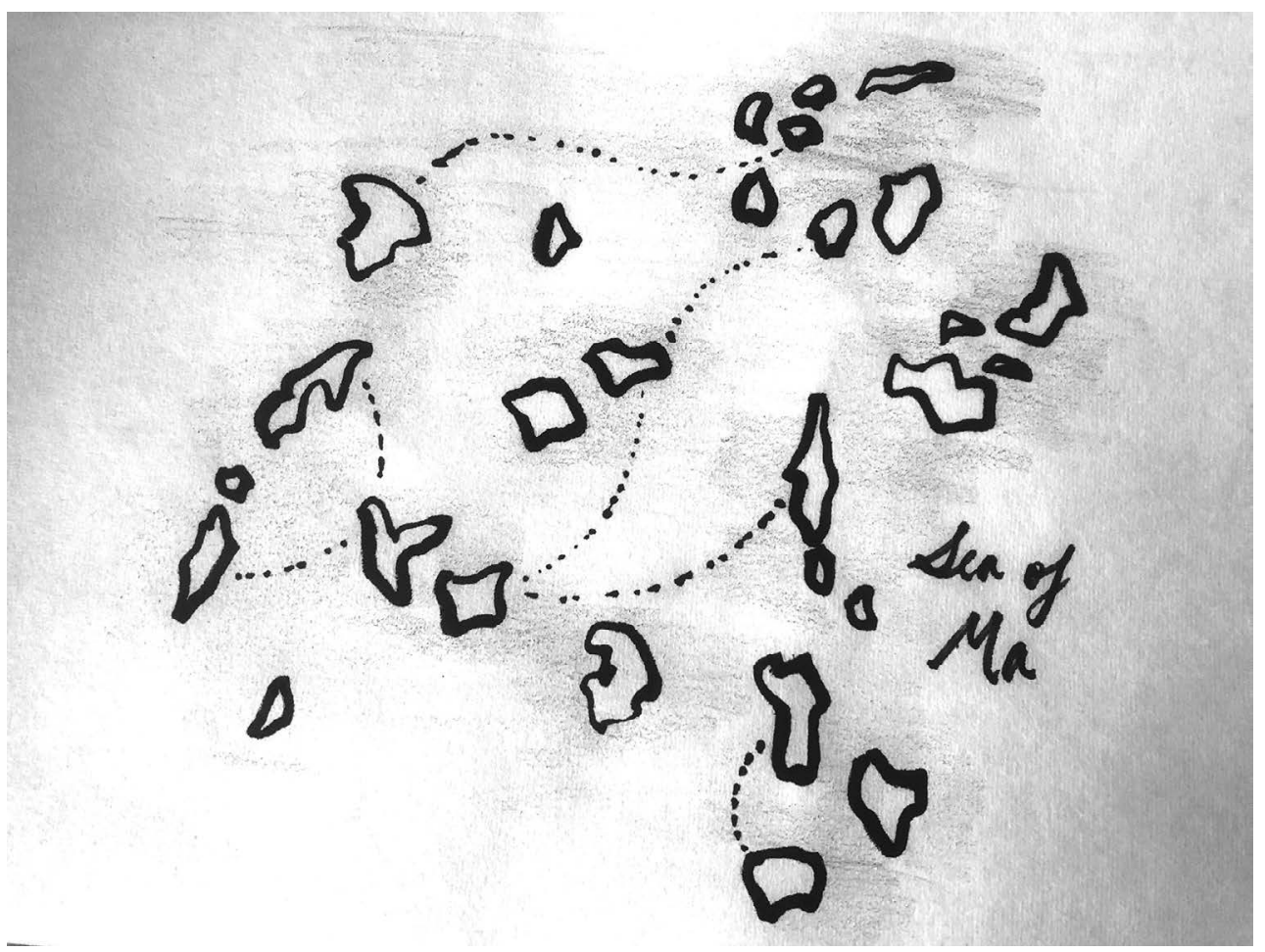

Figure 6.4 Sea of Ma.

colonisation. Just as the need to be vigilant to read the tides, rips, swells and depth when entering any body of water, we must also be attentive, responsive and reflexive at all times in the Sea of $M a$ to engage with difference with respect and sensitivity. This includes attending to the values that lie under the surface and how these are expressed and negotiated through our practices when we design and research with others, including more-than-humans. It is an ethical and political vigilance to deeply engage with mind-body-heart-spirit and honour the 'distinctions between the relationships of things' and 'spaces for plural ethical relationships' (Oliver, forthcoming).

When we are no longer victims of whiteness, we can encounter one another in this Sea of Ma. My stories shared at the start is an Acknowledgement of being relationally emplaced. My explorations in writing-reading is another way I am aiming to engage with you through ko-ontological inter-becoming. I welcome all to share how designing is constituted by many stories, relationality and positionalities in plural worlds. Locating ourselves is one way we can understand what we are holding on to and carrying with us, so we can avoid appropriating, flattening and dividing. It is a way of being respectful to our primordial entanglements, dependencies and co-emergence, that obliges us to feel, think, act, imagine and become-with-many. In doing so, I am hopeful that we can embrace many practices as designing and research so we can confidently depart the Continent's shores. This also means to abandon logical constructs that invalidate contradictions and paradoxes, and collapse them under universalisms 
or categorisation of sameness. When such logical temptations occur, let us enact rituals such as walking, gardening, swimming or preparing food that have been practised over-and-over-and-over-and-over again that can deepen one's relationship with diverse ecologies. This can remind us of the delightfulness of contrasting flavours, distant correspondence between the moon and tides, and how life cannot be without the reciprocities of decay.

The plurality of archipelagos means that many worlds exist simultaneously, and often in close proximity. If being entangled is already our pre-existing condition, it compels us to act within an obligation, responsiveness and responsibility. I have shared one example as kokoro of designing that inspires me from the archipelagos of Japan, but as we know, there are many archipelagos of designing that can also be our initial navigating guide. As we set sail in the Sea of $M a$, it is my hope that the Continent will then shrink in dominance in our view and in our being, as we move further towards becoming-with archipelagos.

\section{Acknowledgements}

Serendipitously, the time of drafting this chapter coincided with encounters with a variety of researchers whose work has inspired my thinking: Shana Agid, Myriam Doremy Diatta, Diana Albarrán González, Josh Creighton, Paulene Mackell, Ricardo Goncalves, Tristan Schultz and Peter West, and the ongoing conversations with the Expanded Writing Group led by Lucinda Strahan at the non-fiction lab, RMIT University. I also thank Andrea Botero, James Oliver and Sarah Teasley for their generous input and comments on my drafts, and the academic editor for providing assistance with my English.

\section{Notes}

1. Video recorded on Wurrundjeri land (password: Mindfulness2020). https://vimeo.com/285071671

2. Modern Design in Japan emerged during the Meiji Restoration (1868-1912). Colonisation was rampant across Asia during this time, and Japan, wanting to avoid invasion by foreign aggressors, rapidly industrialised, Westernised and centralised the emperor's power. Modern design is an outcome of Western culture that was imported, imitated and assimilated in a bid to 'attain parity with the great powers' (Yasuda, 1917, p. 51), and used in the militarisation and colonisation by the imperial state (Adriasola et al., 2016). Design一or『デザイン』as it is referred to in Japan-is written in katakana script to indicate this imported origin.

3. Sakuteiki (The Book of Garden) by Tachibana no Toshitsuna (1028-1094) provides a compilation of techniques used to create the shinden-zukuri garden for temples. It is considered as one of the oldest publications on garden design in Japan (Tachibana, 1976).

4. Ujiko is similar to a shrine 'parishioner', referring to those connected to the shrine or deity.

5. Adding '-san' is common for names, so attributing this to Ise signals a relational intimacy.

6. A fragment of my text from the 'Writing With the Virus' project with the Expanded Writing Group during COVID-19.

\section{References}

Adams, G., \& Salter, P. S. (2019). They (color) blinded me with science: Counteracting coloniality of knowledge in hegemonic psychology. In K. W. Crenshaw (Ed.), Seeing race again: Countering colorblindness across the disciplines (pp. 271-292). University of California Press.

Adriasola, I., Teasley, S., \& Traganou, J. (2016). Design and society in modern Japan: An introduction. Review of Japanese Culture and Society, 28, 1-50. 


\section{Yoko Akama}

Agid, S., \& Akama, Y. (2018). Dance of designing: Rethinking position, relation and movement in service design. In A. Meroni (Ed.), ServDes2018: Proof of concept. Politecnico Di Milano.

Agid, S., \& Chin, E. (2019). Making and negotiating value: Design and collaboration with community led groups community led groups. CoDesign, 15(1), 75-89.

Ahmed, S. (2011). A phenomenology of whiteness. Feminist Theory, 8(2).

Ahmed, S. (2012). On being included: Racism and diversity in institutional life. Duke University Press.

Akama, Y. (2015). Being awake to Ma: Designing in between-ness as a way of becoming with. Co-Design: International Journal of CoCreation in Design and the Arts, 11(3-4), 262-274.

Akama, Y. (2018). Surrendering to the ocean: Practices of mindfulness and presence in designing. In R. B. Egenhoefer (Ed.), The Routledge handbook of sustainable design (pp. 219-230). Routledge.

Akama, Y., Hagen, P., \& Whaanga-Schollum, D. (2019). Problematizing replicable design to practice respectful, reciprocal, and relational co-designing with Indigenous people. Design and Culture, 11(1), 59-84.

Akama, Y., \& Light, A. (2018). Practices of readiness: Punctuation, poise and the contingencies of participatory design. Proceedings of the Participatory Design Conference. Hasselt, Belgium, Proceedings in PDC'18.

Albarrán González, D. (2020). Towards a buen vivir-centric design: Decolonising artisanal design with Mayan weavers from the highlands of Chiapas, Mexico [Doctoral dissertation, Auckland University of Technology].

Asahi Newspaper. (2020). Mie kaigen de chümoku Ise Jingu Sanpai kyonen wa 973man-nin [Noticing the changing era Mie prefecture Ise Srhine visitors last year 9,730,000]. www. asahi.com/articles/ASN183RPMN18ONFB005.html

Barrett, E., \& Bolt, B. (2007). Practice as research: Approaches to creative arts enquiry. I. B. Tauris \& Co.

Bidwell, N. (2016). Decolonising HCI and interaction design discourse: Some considerations in planning AfriCHI. XRDS: Crossroads, the ACM Magazine for Students: Cultures of Computing, 22(4), 22-27.

Browning, D., Greenaway, J., Herzich, P., Monks, N., \& Ball, T. (2017). Does blak design matter? In D. Browning (Ed.), AWAYE! ABC Radio National. www.abc.net.au/radionational/ programs/awaye/does-blak-design-matter/8410232

Calderón Salazar, P., \& Guitérrez Borrero, A. (2017). Letters South of (Nordic) design. Proceedings of NORDES (Vol. 7, pp. 1-11). The Oslo School of Architecture and Design, Norway.

Carter, P. (2019). Decolonising governance. Routledge.

Collins, P. (1990). Black feminist thought in the matrix of domination. In Black feminist thought: Knowledge, consciousness, and the politics of empowerment (pp. 221-238). Unwin Hyman.

Crenshaw, K. W. (Ed.). (2019). Seeing race again: Countering colorblindness across the disciplines. University of California Press.

Davidson, C. (Ed.). (1991). Anyone, anyone corporation. Rizzoli International.

Dilworth, D. A., Vigielmo, V. H., \& Zavala, A. J. (1998). Chapter one Nishida Kitaro. In D. A. Dilworth, V. H. Vigielmo, \& A. J. Zavala (Eds.), Sourcebook for modern Japanese philosophy: Selected documents (pp. 1-20). Greenwood Press.

Elfers, J., \& Hlava, P. (2016). The spectrum of gratitude experience. Palgrave Macmillan.

Escobar, A. (2018). Designs for the pluriverse: Radical interdependence, autonomy and the making of worlds. Duke University Press.

Fanon, F. (1994). Black skin, white masks (Reissued ed.). Avalon Travel Publishing.

Geraci, R. M. (2006). Spiritual robots: Religion and our scientific view of the natural world. Theology and Science, 4(3), 229-246.

Gerding, J. (2019). The sounds of silence. In K. W. Crenshaw (Ed.), Seeing race again: Countering colorblindness across the disciplines (pp. 23-51). University of California Press.

Giddens, A. (1984). The construction of society. Polity Press. 
Gomi, F., \& Toriumi, Y. (Eds.). (2009). Mou ichido yomu Yamakawa Nihonnshi [Read Yamakawa Japanese history again]. Yamakawa Publishers.

Hara, K. (2011). White. Lars Müller.

Hau'ofa, E. (1994). Our sea of islands. The Contemporary Pacific, 6(1), 147-161.

Hayashi, K. (1997). Ise Jingu seiritsu shikō [Theory of the establishment of Ise Jingu]. Kenchiku shigaku Journal, 28, 75-110. https://doi.org/10.24574/jsahj.28.0_75

Hofstede, G. (1994). Cultures and organizations: Intercultural co-operation and its survival: Software of the mind. Harper Collins.

Inoue, N., Endo, J., Mori, M., \& Ito, S. (2003). Shinto: A short history. Routledge.

International Indigenous Design Charter. (n.d.). http://indigenousdesigncharter.com.au/ international-indigenous-design-charter/

Irani, L. (2018). Design thinking: Defending Silicon Valley at the apex of global labor hierarchies. Irani Catalyst, 4(41), 1-19.

Isozaki, A. (2011). Japan-ness in architecture (D. B. Stewart, Ed.; S. Kohso, Trans.). MIT Press.

Itaya, H. (1860). Hyakki Yagyo. www.artgallery.nsw.gov.au/collection/works/125.1995/

Jordan, J. (1985). On call: Political essays. South End Press.

Kanai, A. (2009). Karoshi (work to death) in Japan. Journal of Business Ethics, 84(2), 209.

Kasulis, T. (2002). Intimacy or integrity: Philosophical and cultural difference. University of Hawaii Press.

Law, J. (2011). What's wrong with a one-world world. Center for the Humanities, Wesleyan University. www.heterogeneities.net/publications/Law2011WhatsWrongWithAOneWorldWorld.pdf

Lindström, K., \& Ståhl, A. (2020, June 15-20). Un/making in the aftermath of design. Proceedings of the 16th Participatory Design Conference 2020: Participation(s) Otherwise-Vol 1 (PDC '20: Vol. 1), Manizales, Colombia. ACM, New York, NY, USA, 10 pages. https://doi. org/10.1145/3385010.3385012

Loo, T. M. (2010). Escaping its past: Recasting the Grand Shrine of Ise. Inter-Asia Cultural Studies, 11(3), 375-392.

Lorde, A. (2018). The master's tools will never dismantle the master's house. Penguin.

Marra, M. (2011). Nativist hermeneutics: The interpretative strategies of Motoori Norinaga and Fujitani Mitsue. In Essays on Japan: Between aesthetics and literature (pp. 365-415). Brill.

McEntee, K., Brandalise, I., Goncalves, R. D., Riendeau, S., Thao, K., \& Grocott, L. (2016). Archipelago of possibilities: Priming teachers to reflect on intrinsic motivations for change. Pilot Project Report: ILETC Project: The University of Melbourne. www.iletc.com.au/ wp-content/uploads/2016/03/archipelago-report-for-ILETC-project.pdf

Moran, C., Harrington, G., \& Sheehan, N. (2018). On country learning. Design and Culture, 10(1), 71-79.

Nakata, M. (2007). The cultural interface. The Australian Journal of Indigenous Education, 36, 7-14.

Ogbonnaya-Ogburu, I. F., Smith, A. D. R., To, A., \& Toyama, K. (2020). Critical race theory. Proceedings of 2020 CHI Conference on Human Factors in Computing Systems (pp. 1-16). https://doi.org/10.1145/3313831.3376392

Oliver, J. (forthcoming). Islandness: Articulating and emplacing relationality. In K. Burnett, R. Burnett, \& M. Danson (Eds.), Scotland and islandness: Explorations in community, economy and culture. Peter Lang.

Onafuwa, D. (2018). Allies and decoloniality: A review of the intersectional perspectives on design, politics, and power symposium. Design and Culture, 10(1), 7-15.

Pugh, J. (2013). Island movements: Thinking with the Archipelago. Island Studies Journal, 8(1), 9-24.

Rambelli, F. (2014). Floating signifiers: The plural significance of the Grand Shrine of Ise and the incessant re-signification of Shinto. Japan Review, 27(27), 221-242.

Reynolds, J. M. (2001). Ise Shrine and a modernist construction of Japanese tradition. The Art Bulletin (New York, N.Y.), 83(2), 316-341. 


\section{Yoko Akama}

Rizvi, U. Z. (2018). Critical heritage and participatory discourse in the UAE. Design and Culture, 10(1), 55-70.

RMIT. (2020). Bundjil's statement: Living and working lawfully on place. https://next.rmit/ inspiration/bundjils-statement-living-and-working-lawfully-on-place/

Rose, D. B. (2004). Reports from a wild country: Ethics for decolonisation. University of New South Wales.

Schultz, T. (2018). Mapping Indigenous futures: Decolonising techno-colonising designs. Strategic Design Research Journal, 11(2), 79-91.

Simon, H. A. (1968). The sciences of the artificial. MIT Press.

Stratford, E., Baldacchino, G., Mcmahon, E., Farbotko, C., \& Harwood, A. (2011). Envisioning the archipelago. Island Studies Journal, 6(2), 113-130.

Suchman, L. (2002). Located accountabilities in technology production. Scandinavian Journal of Information Systems, 12(2), 91-105.

Suzuki, D. T. (1969). An introduction to Zen Buddhism. Rider and Company.

Tachibana, T. (1976). Sakuteiki, the book of garden (a full translation of the Japanese eleventh century manuscript: Memoranda on garden making). Town \& City Planners Publishers.

Teeuwen, M., \& Breen, J. (2017). A social history of the Ise Shrines: Divine capital. Bloomsbury.

Tlostanova, M. (2017). On decolonizing design. Design Philosophy Papers, 15(1), 51-61.

Tuck, E., \& Yang, K. W. (2012). Decolonization is not a metaphor. Decolonization, Indigeneity, Education \& Society, 1(1), 1-40.

Tye, A. L., Akama, Y., Elliott, L., Keen, S., McMillan, F., McMillan, M., \& West, P. (2020). Weaving and yarning sovereign relationships. Kairos: A Journal of Rhetoric, Technology, and Pedagogy, 24(2). http://kairos.technorhetoric.net/24.2/inventio/tye-et-al/index.html

Walker, S. (2013). Design and spirituality: Material culture for a wisdom economy. Design Issues, 29(3), 89-107.

West, P. (2020). Designing in response to Indigenous sovereignties. Proceedings of ServDes.2020: Tensions, Paradoxes, Plurality, Melbourne, Australia, Linköping University Electronic Press.

Willis, A.-M. (2006). Ontological designing. Design Philosophy Papers, 2, 1-11.

Yamada, T. (1966). Shinto symbols (continued). Contemporary Religions in Japan, 7(2), 89-142.

Yasuda, R. (2016/1917). Japan's industrial arts: Present and future. In I. Adriasola, S. Teasley, \& J. Traganou (Eds.), Design and society in modern Japan: An introduction to design and society in modern Japan (Vol. 28, pp. 51-54). Josai University Educational Corporation.

Yee, J., Akama, Y., Teerapong, K., \& Petrella, V.(2020). Creative and cultural districts in Thailand. A report for the British Council Thailand. www.britishcouncil.or.th/en/programmes/arts/ creative-hubs/research-creative-and-cultural-districts-thailand 